police forces captured the $17 \mathrm{~N}$ leaders, which significantly weakened the organization.

Each of the listed organizations is presented in a concise and analytical way, from the historical background to the contemporary situation. The Lexicon will be of use to anyone interested in international matters, especially to the students of political sciences, including international relations, as well as to anyone looking for a modern tool to understanding one of the biggest problems of the contemporary world. The relevance of terrorism as a threat to the civilized world order is proven by the fact that this monograph is a part of the research project named "Domestic and International Aspects of Terrorism" and realized by an international team of political scientists, lawyers, sociologists, economists and historians.

\title{
Book review: Bartłomiej Michalak, Protes Parties in Western Europe. Analysis of Political Relevance (Partie protestu w Europie Zachodniej. Analiza relewancji politycznej), Wydawnictwo Adam Marszałek, Toruń 2008, pp. 312
}

\section{Alfred Lutrzykowski}

Protes Parties in Western Europe. Analysis of Political Relevance by Bartłomiej Michalak is a book that deserves attention of wide range of readers, who are willing to deepen their knowledge concerning transformations of contemporary party systems. It is political parties that since nearly two centuries are a phenomenon of European political life. In other parts of the world they bring attention of not only researchers, but also of constantly growing social groups. Today, political life of any society is hard imaginable without parties, its coalitions, contentions and conflicts as well as almost constant presence of parties' leaders and activists in everyday life of millions of citizens of big metropolis and distant provinces.

Political parties in their history went through a complicated evolution, becoming the main powers that activate and organize participants of the battle for state power or at least for possessing an authentic influence on it. In that time party systems have taken shape, which is more or less proper mapping of the social powers configuration as well as level of power of certain political parties. As the consolidation of national political systems went further party systems showed tendencies to petrify static configurations and to create processes among party relations' schemes.

However, the dynamics of political life has led to disturb the preserved-to-some-extent balance and (at the end) to changes of the inner mechanism and various (types of) political systems. In Western Europe some symptoms of party systems 'refreezing' appeared. One of its main causes leading to that type of change was presence on the political stage of the new factions, which were guided by various motives, and which began to aspire to active and direct participa- 
tion in the game for power. These were also the consolidating factions that had (and still have) a anti-system character. And so in the atmosphere of criticism of the then configuration of political powers as well as axiology, methods and techniques of exercising power the so-called protest parties appeared. They arose based on ideas and movements such as proenvironmentalists, populists anti/ alterglobalists etc.

The book is the dedicated to the issues of protest parties and movements. The author took up an ambitious attempt of presenting the phenomena of these parties, putting special attention to features that link them as well as results that they cause in party systems wherever they have appeared. The aim of the analysis is to determine the level of relevance of the protest parties, meaning to answer a question whether their existence is important to the general shape and mechanisms of the party systems. The author seeks answers to that questions by analyzing processes that take have taken place in Western Europe' party systems between 1953 and 2005 (see p. 10-11).

The author by stating the main hypothesis of his research, assumes that "the protest parties owing to level of gained support have become fully politically relevant" (p. 14). Their 'value' manifests in the whole space of interaction between parties. It shows a growth tendency, which means that they are not political ephemerides. As integral particles of party systems they've achieved a good position in order to influence the direction of system evolution and especially the hitherto process of interparty interactions model (cooperation and competitiveness).
In the 'Summary' the author states that "researches and observations have confirmed the hypothesis fully (...) Protest parties have proved that in a long period they are capable of gaining enough political relevance in order to permanently influence the pattern of political competitiveness and the character of the system" (p. 289).

The composition of the reviewed work is logical, consequent and coherent. Precise determining the subject of the issue allows to unambiguously place it on this wide field of topics of functioning and characteristics of contemporary party systems. The author, by presenting the key category - relevance, points out the group of issues on which his search for factors that create relevance of this parties is based on.

Protest parties were getting into the system and they considerably contributed to redefinition of its composition. It shall be then emphasized that the author, despite his fascination of the protest parties phenomenon expressed in the book, keeps a distance to their successes. He doesn't overvalue their anti-system power, pointing on high adaptive capabilities of the traditional political factions.

Comprehensive 'Summary' (p. 265-293) is a display of authors' erudition and a very good knowledge of that issue. Despite the fact that he repeats some judgments that are found in certain chapters, this part of the work receives my recognition. We can find here mature, presented sine ira et studio, answers to questions stated in hypotheses. Once more, this time in a systematic form, the author analyses and asses factors that contributed to the difficult, but in most cases 
successful, march of protest parties, that have become important particles of party systems of Western Europe countries. The author presents great restraint while assessing phenomenon or links between them that are not fully recognized. He does so in case of the hypothesis of "the link between appearance of sense of subjective deprivation of some social groups (...) and growth of number of the 'unsatisfied' voters as the natural basis for protest movements", claiming that this link is "plausible", but he also states that one cannot undoubtedly confirm it (p. 284).

Also remarks and judgments regarding the so-called consensual democracy are convincing (p.288). Similar restraint one can notice when the author describes the actual place (in my opinion it shall say "former") of protest parties, which - in the process of routinization - to certain extent have petri- fied their political position. In none of the cases they can not endanger the traditional parties' domination, but they have the potential to destabilize current system. This however "has always ended up with another stabilization, and this time on a higher level" (p. 293).

The book contains also list of parties names' abbreviations as well as list of figures and tables. Rich bibliography informs about very valuable literature and other sources which has been used by the author. The 'Appendix' is composed of information about dates of following elections in which protest parties took part, as well as data about gained support.

The reviewed book is a very good inspiration to further research on protest parties as they are real actors in our part of Europe and in Poland too. This second factor makes the issue even more attractive. 